\title{
Design, fabrication and SNOM investigation of plasmonic devices
}

Malureanu, Radu; Zenin, Vladimir A.; Andryieuski, Andrei; Radko, llya P.; Volkov, Valentyn S.; Gramotnev, Dmitri K.; Lavrinenko, Andrei; Bozhevolnyi, Sergey I.

Link to article, DOI:

10.1109/PIERS.2016.7734237

Publication date:

2016

Document Version

Publisher's PDF, also known as Version of record

Link back to DTU Orbit

Citation (APA):

Malureanu, R., Zenin, V. A., Andryieuski, A., Radko, I. P., Volkov, V. S., Gramotnev, D. K., Lavrinenko, A., \& Bozhevolnyi, S. I. (2016). Design, fabrication and SNOM investigation of plasmonic devices. Abstract from Progress In Electromagnetics Research Symposium 2016, Shanghai, China.

https://doi.org/10.1109/PIERS.2016.7734237

\section{General rights}

Copyright and moral rights for the publications made accessible in the public portal are retained by the authors and/or other copyright owners and it is a condition of accessing publications that users recognise and abide by the legal requirements associated with these rights.

- Users may download and print one copy of any publication from the public portal for the purpose of private study or research.

- You may not further distribute the material or use it for any profit-making activity or commercial gain

- You may freely distribute the URL identifying the publication in the public portal 


\title{
Design, Fabrication and SNOM Investigation of Plasmonic Devices
}

\author{
Radu Malureanu ${ }^{1}$, Vladimir A. Zenin ${ }^{2}$, Andrei Andryieuski ${ }^{1}$, \\ Ilya P. Radko ${ }^{2}$, Valentyn S. Volkov ${ }^{2}$, Dmitri K. Gramotnev ${ }^{3}$, \\ Andrei V. Lavrinenko ${ }^{1}$, and Sergey I. Bozhevolnyi ${ }^{2}$ \\ ${ }^{1}$ DTU Fotonik, Technical University of Denmark, Kgs. Lyngby, Denmark \\ ${ }^{2}$ Centre for Nano Optics, University of Southern Denmark, Odense, Denmark \\ ${ }^{3}$ Nanophotonics Pty. Ltd., Albany Creek, Queensland, Australia
}

\begin{abstract}
Surface plasmon-polaritons are a possible solution for on-chip transportation and manipulation of information. Although there are several possibilities for designing the plasmonic waveguides, the two major caveats for all of them are the coupling to/from external sources and the losses they exhibit.

In this work we will present an overview of our simulation, fabrication and characterisation activity in the plasmonic field where we tackle these issues.

We start with presenting an optimised nanoantenna for coupling of free-propagating waves into a subwavelength slot waveguide modes [1]. Optimised antennae show an increase in coupling efficiency up to 185 times compared to a bare waveguide.

Once optimized, the nanoantennae were fabricated and the propagation in the slot waveguides was characterised [2]. The characterisation shows an increase in the effective area (proportional to the coupling efficiency) of up to 175 times, similar to the calculated optimised parameters.

We then move our attention to effective tapering of the plasmonic modes such that to achieve either strong field enhancement [3] or propagation into thin plasmonic nanowires [4]. Using onchip nanofocusing with impedance-matched nanoantenna we can obtain a field enhancement of up to $\sim 12000$ evenly distributed in a volume of $\sim 30 \times 30 \times 10 \mathrm{~nm}^{3}$. The same taper can be used also for modifying the waveguide profile from a wide strip waveguide to a nanorod waveguide showing both the flexibility of our taper design as well as allowing to measure and compare the propagation characteristics in waveguides with various widths. We show that the propagation length matches very well the theoretical one and also obtain a limit for confinement of the mode in this type of plasmonic waveguides of $\sim \lambda / 15$.
\end{abstract}

\section{REFERENCES}

1. Andryieuski, A., et al., Optics Lett., Vol. 37, No. 6, 2012.

2. Andryieuski, A., et al., Nanoletters, Vol. 14, 2014.

3. Zenin, V. A., et al., Nano Lett., Vol. 15, No. 12, 2015.

4. Zenin, V. A., et al., Optics Express, 2016, to be published 